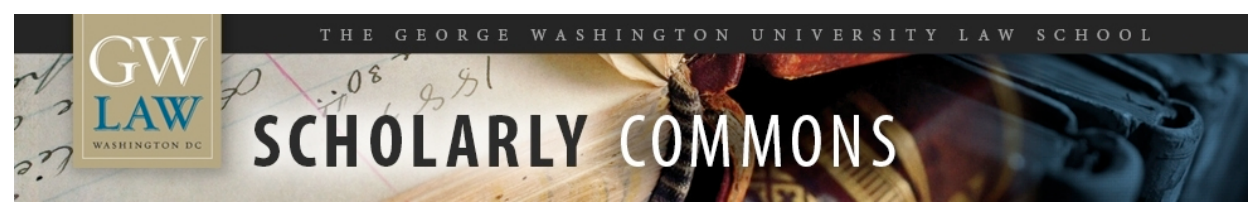

\title{
The U.S. Federal Procurement System: An Introduction
}

Christopher R. Yukins

George Washington University Law School, cyukins@law.gwu.edu

Follow this and additional works at: https://scholarship.law.gwu.edu/faculty_publications

Part of the Law Commons

\section{Recommended Citation}

Yukins, Christopher R., The U.S. Federal Procurement System: An Introduction (November 1, 2017). Christopher R. Yukins, The U.S. Federal Procurement System: An Introduction, 2017 UPPHANDLINGSRÄTTSLIG TIDSKRIFT 69, https://www.urt.cc/?q=node/187.; GWU Law School Public Law Research Paper No. 2017-75; GWU Legal Studies Research Paper No. 2017-75. Available at SSRN: https://ssrn.com/abstract $=3063559$

This Article is brought to you for free and open access by the Faculty Scholarship at Scholarly Commons. It has been accepted for inclusion in GW Law Faculty Publications \& Other Works by an authorized administrator of Scholarly Commons. For more information, please contact spagel@law.gwu.edu. 


\section{Christopher R. Yukins}

The U.S. Federal Procurement System:

An Introduction

$$
2017 \text { no } 2 / 3
$$

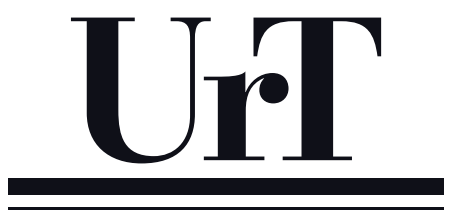




\title{
The U.S. Federal Procurement System: An Introduction
}

\author{
By Christopher R. Yukins*
}

The U.S. procurement market is one of the largest in the world, ${ }^{1}$ and the procurement law which guides that market, a regulatory regime which is both complex and mature, ${ }^{2}$ offers important lessons for other procurement systems around the world. This article provides a modest introduction to U.S. procurement law especially federal procurement law, which generally is more extensively developed than state or local procurement law ${ }^{3}$ - and suggests possible lessons learned that may be useful for other systems.

The article proceeds in several parts. Part I reviews the history of the federal procurement system, which can be traced to the Revolutionary War. That initial part also discusses the contract administration regime that the federal government has developed - a separate system, uniquely independent from commercial law - and argues that setting the U.S. procurement law regime apart from commercial law makes sense because of the unique requirements (and risk allocations) between the government and its contractors. Part II discusses access to the market, through transparency for example, and because of international trade agreements guaranteeing non-discrimination and national treatment. Part III discusses leading procurement methods in federal procurement, with a special emphasis on the multilateral competitive negotiations that had, by the end of the twentieth century, become a mainstay of complex federal procurements. Part IV discusses

\footnotetext{
Christopher Yukins (cyukins@law.gwu.edu) is the Lynn David Research Professor in Government Procurement Law and Co-Director of the Government Procurement Law Program at the George Washington University (GWU) Law School, Washington, D.C. That program was launched in 1960 by Professors Ralph Nash, Jr. and John Cibinic, Jr. See https://www.law.gwu.edu/government-procurement-law.

1 For data on federal procurement spending, see www.usaspending.gov. Federal government procurement totals approximately US $\$ 500$ billion per year. Id.

2 The law library at the GWU Law School has one of the leading collections on public procurement law (traditionally called "government contracts law" in the United States), and the librarians there, coordinated by subject matter expert Mary Kate Hunter, mhunter@law.gwu.edu, have compiled guides to support research on procurement law. See, e.g., The Jacob Burns Law Library Research Guides, Government Contracts Resources, available at http://law.gwu.libguides.com/govk; The George Washington University Law School, Jacob Burns Law Library, Government Contracts Research, available at https://www.law.gwu.edu/sites/www.law.gwu.edu/files/downloads/SRG_1_ GovernmentContracts.pdf.

3 See, e.g., Danielle Conway, State and Local Government Procurement (American Bar Association 2012); American Bar Association, Model Code for State and Local Governments (2000), available at http://apps.americanbar.org/dch/committee.cfm?com=PC500500; Guide to State Procurement: A 50-State Primer on Purchasing Laws, Processes, and Procedures (Melissa Javon Copeland, ed., ABA 2 d ed. 2016).
} 
the leading contract types (fixed-price and cost-reimbursement contracts), and explains the strategic advantage that the United States gains through an effective cost-reimbursement contracting system. Part V discusses bid challenges (called "bid protests" in the U.S. system) by disappointed bidders. Part VI reviews some of the leading anti-corruption elements in the U.S. system; these are critical to the evolution of the U.S. federal system, as (for example) it would have been impossible to use riskier competitive negotiations without effective anti-corruption protections. The piece concludes by arguing that although the U.S. procurement regime is mature it continues to evolve and, given the striking parallels between the U.S. system and its counterparts abroad, there will be ample opportunity to share lessons learned in the years ahead.

\section{A Brief History of the U.S. Federal Procurement System}

The history of the federal procurement system in the United States has, in many ways, been shaped by armed conflict. ${ }^{4}$ Through a number of wrenching wars, the U.S. procurement system fumbled through a long series of mistakes - and internalized the lessons learned from those mistakes. Because the procurement system was guided by relatively constant principles 5 and a written set of rules that evolved over time, the federal procurement system, bound by laws and led by officials with real respect for the rule of law, was able to accumulate its lessons learned over several centuries. Those lessons spanned beyond contract formation, to include bid challenges, contract administration, disputes and appropriations law - developments on many fronts which resulted in a highly complex procurement system that continues to evolve today.

Important patterns in modern federal procurement can be traced back to the Revolutionary War, when the Continental Congress several times organized, and reorganized, the procurement system to supply the Continental Army. ${ }^{6}$ That very intimate relationship between Congress and procurement (especially defense procurement) continues today; indeed, many modern procurement reforms are launched through the annual authorizing legislation for the U.S. Department of Defense. ${ }^{7}$ That annual defense authorization legislation, which has consistently passed for over 50 years, offers Congress a ready means to continue its long

4 See, e.g., Clifton E. Mack, Procurement Division, U.S. Department of Treasury, Federal Procurement: A Manual for the Information of Federal Purchasing Officers viii (1943).

5 See, e.g., Steven L. Schooner, Desiderata: Objectives for a System of Government Contract Law, 11 Pub. Proc. L. Rev. 103 (2002), available at http://ssrn.com/abstract=304620.

6 See James F. Nagle, History of Government Contracting 16-54 (2d ed. 1999).

7 The annual National Defense Authorization Act (NDAA) can be tracked through the U.S. Congress' home page, www.congress.gov. 
tradition of tinkering with - improving, through trial and error - the federal procurement system.

As the new nation came into being, Congress passed the first laws specifically authorizing procurement by a formal contracting process, laws which called for notice, competition and public award. ${ }^{8}$ The new United States inherited this traditional contracting system from Europe'; several centuries later, in a historical turnabout, the United States would play a prominent role in an international shift to multilateral negotiations, called "competitive negotiations" in the U.S. system. ${ }^{10}$

From early on, the federal system developed a means of addressing contractor qualification - what is now called "responsibility" under Federal Acquisition Regulation (FAR) ${ }^{11}$ Part 9. ${ }^{12}$ Only "men of substance and talents" were allowed to win government contracts, ${ }^{13}$ a precursor to today's highly evolved qualification system to assess prospective contractors' potential reputational and performance risks. During these early decades of the republic, the federal government also began to delegate substantial discretion to contracting officers. ${ }^{14}$ Much as the federal procurement system relies on "responsible" contractors, so too does it depend on professional and highly engaged contracting officers, who (like "responsible" contractors) sharply reduce the risks of corruption and performance failure. ${ }^{15}$

By the beginning of the nineteenth century, the system of structured solicitations and competitive awards, based on low price, was well-established, built through practical experience such as awards of stagecoach transportation contracts by the young government. The principle that when it contracts the government acts not as a sovereign, but as a contracting party subject to the rule of law, grew up with the system; that principle, and the concomitant assumptions that the government must act in good faith and is subject to a disputes process, evolved as bedrock principles of the U.S. system. ${ }^{16}$

Over the first century of the new republic, before the Civil War began in 1861, the federal government worked to develop its own manufacturing capacity, includ-

\footnotetext{
8 See, e.g., Patricia Wittie, Origins and History of Competition Requirements in Federal Government Contracting: There's Nothing New Under the Sun, at 1-4 (citing early legislative authorities and online resources available through the U.S. Library of Congress), available at www.reedsmith.com.

9 See James F. Nagle, supra note 6, at 47-48.

10 See FAR Part 15. In other systems, these multilateral negotiations are sometimes called "competitive dialogue"; under Article 29 of European procurement directive 2014/24/EU, a similar method of competitive negotiations is called "competitive procedure with negotiation."

11 See infra note 45 and accompanying text.

12 See, e.g., John Cibinic, Jr., Ralph Nash Jr. \& Christopher R. Yukins, Formation of Government Contracts ch. 4 (4th ed. 2011) [hereinafter Formation of Government Contracts].

13 See James F. Nagle, supra note 6, at 50.

${ }_{14} \mathrm{Id}$. at 71

15 One of the largest organizations of contracting professionals, from both the public and the private sectors, is the National Contract Management Association, www.ncmahq.org.

16 See James F. Nagle, supra note 6, at 52-72.
} 
ing its own armories, so that ultimately the government would not need to rely on foreign arms manufacturers. ${ }^{17}$ This was in keeping with attitudes that persist in federal procurement today: there is consensus on the need to ensure "security of supply" - ready access to vital materiel in a time of war. ${ }^{18}$ Over this first century of its history, the federal government often relied on its own armories, favoring "make" over "buy" (to paraphrase); this balance between internal production and outsourcing from contractors was driven, in part, by the government's technological dominance in the early phases of American industrialization. (For example, Harpers Ferry Armory, the scene of abolitionist John Brown's 1859 raid which helped launch the Civil War, was a U.S. government-owned gun factory.) The government's technological lead largely faded by the end of the twentieth century; by that point, the private sector was almost always well ahead of the government, and that new asymmetry - that new and durable technological lead in the private sector - helped shape the modern procurement methods discussed below.

From very early on, the government and its contractors began to develop the legal constructs that define their relationships today, often under the stresses of wartime production. In his masterful work on the U.S. system, History of Government Contracting, James Nagle describes for example how federal officials jousted with renowned inventor and manufacturer Eli Whitney over his company's huge delays in delivering contracted-for guns. ${ }^{19}$ The angry back-and-forth between the officials and Whitney, and similar early contretemps author Jim Nagle describes, help explain the severe rules that ultimately grew up around terminations for default, as the government clearly needs a strong "stick" to ensure performance. At the same time, these histories of protracted wrestling between the government and its contractors - a struggle that often stops short of termination - illustrate government officials' risk-averse reluctance to incur the delay and embarrassment of termination. That reluctance to terminate in turn helps explain other legal doctrines, such as expansive inspection powers, ${ }^{20}$ demands for strict compliance with requirements ${ }^{21}$ and payment presumptively only after performance, ${ }^{22}$ which give the government additional leverage in these battles with contractors.

Wartime contracting also helped launch another important doctrine: termination for convenience. ${ }^{23}$ Under that doctrine, the government may terminate

17 Id. at 72 .

18 Cf. European Defence Agency, Directorate General Internal Market and Services, Directive 2009/81/ $E C$ on the award of contracts in the fields of defence and security - Guidance Note: Security of Supply (discussing concept), available at https://www.eda.europa.eu/docs/documents/guide-sos_en.pdf.

19 See James F. Nagle, supra note 6, at 75-84.

20 See, e.g., FAR 52.246-2, Inspection of Supplies - Fixed-Price (standard inspection clause).

21 John Cibinic, Jr., Ralph Nash, Jr. \& James F. Nagle, Administration of Government Contracts 815 (4th ed. 2006) [hereinafter Administration of Government Contracts].

22 See 31 U.S.C. $\$ 3324$; Administration of Government Contracts, supra note 21, at 1135.

23 See FAR Subpart 49.1. 
a contract for the government's convenience when its need for the good or service at issue falls away. Termination for convenience is a doctrine that really took shape after the widespread terminations of contracts at the end of World War I. The courts confirmed that the government retained the right, as part of its inherent sovereign powers, to terminate contracts unilaterally when circumstances demand - an extraordinary break from commercial rules of contracting. ${ }^{24}$ When the government does terminate for its convenience, the government must compensate the contractor for its lost costs on the contract, though not for lost profits; unsurprisingly, this is a point of concern for many contractors, especially in long-term contracts.

The overall sense of adversity between the government and its contractors stemming, in important part, from government officials' abiding fear that contractors will, if they can, cheat the federal government - also helps explain the draconian penalties for fraud that the U.S. government will impose, both civilly and criminally. The government's actions for civil fraud often stem from a suit brought originally by a whistleblower (a "relator," who by statute may share in the government's recovery from a fraudulent contractor) under the False Claims Act. ${ }^{25}$ The False Claims Act, which has yielded the government and whistleblowers billions of dollars in damages and penalties for fraud, ${ }^{26}$ plays a unique and prominent role in the federal procurement system. With its combination of severe monetary penalties (many thousands of dollars per false "claim"), plus treble damages, low knowledge requirement (a contractor need only be "reckless" to trigger civil fraud liability), and strong incentives for internal "whistleblowers," the U.S. anti-fraud system is arguably one of the most aggressive in the world.

The long and intimate relationship between the government and its contractors has, over time, built a separate federal procurement community, numbering probably over 100,000 people, including hundreds of lawyers who specialize in federal procurement law. The special relationship between the government and its contractors is shaped by a unique set of policy and commercial concerns, and as a result a unique body of law has developed regarding both federal contract formation and administration. The separate body of law governing public contract administration - something few countries have - is supported by the FAR's

\footnotetext{
${ }_{24}$ See Administration of Government Contracts, supra note 21, at 1049-50 (recounting history and authorities regarding terminations for convenience).

25 See generally John T. Boese, Civil False Claims and Qui Tam Actions (Wolters Kluwer $4^{\text {th }}$ ed. 2010); U.S. Department of Justice, The False Claims Act: A Primer, https://www.justice.gov/sites/default/ files/civil/legacy/2011/04/22/C-FRAUDS_FCA_Primer.pdf.

26 See, e.g., U.S. Department of Justice, Press Release: Justice Department Recovers Over \$4.7 Billion From False Claims Act Cases in Fiscal Year 2016 (Dec. 14, 2016) ("This is the third highest annual recovery in False Claims Act history, bringing the fiscal year average to nearly $\$ 4$ billion since fiscal year 2009 , and the total recovery during that period to $\$ 31.3$ billion."), https://www.justice.gov/ $\mathrm{opa} / \mathrm{pr} /$ justice-department-recovers-over-47-billion-false-claims-act-cases-fiscal-year-2016.
} 
standard contract clauses ${ }^{27}$ and the specialized tribunals (the boards of contract appeals, the U.S. Court of Federal Claims, and on appeal the U.S. Court of Appeals for the Federal Circuit $^{28}$ ) that hear cases stemming from contracting officer decisions under the Contract Disputes Act. ${ }^{29}$

Federal procurement law has undergone several important changes over the past few decades, largely driven by Congress. The Competition in Contracting Act of $1984^{30}$ now presumptively requires full-and-open competition in federal procurement, and regularized the role of the Government Accountability Office (GAO) in hearing bid protests (GAO had been hearing protests since the 1920s). ${ }^{31}$ The Federal Acquisition Streamlining Act (FASA) transformed much of the federal statutory structure, and created special authority for federal agencies to purchase commercial items under FAR Part 12 with streamlined rules and procedures. ${ }^{32}$ And FASA's sister legislation, the Clinger-Cohen Act of 1996, furthered FASA's reforms and streamlined information technology procurement - among other things, by eliminating special bid challenges regarding IT acquisitions. ${ }^{33} \mathrm{Leg}-$ islative reforms continue, largely through incremental changes passed (as noted above) through every year's defense authorization legislation.

In closing out this brief history, ${ }^{34}$ it is important to note a companion body of law that has evolved in the U.S. system: fiscal (or appropriations) law, which governs how officials should interpret and spend congressional appropriations. The U.S. Constitution vests Congress with the sole authority to control spending, and to protect that prerogative - often in the wake of profligate misuse of funds by executive officers - Congress has passed laws barring (and sometimes crim-

27 See, e.g., FAR Part 52 (standard clauses).

28 The Civilian Board of Contract Appeals (CBCA) hears appeals regarding contract disputes from most civilian agencies, and the CBCA is complemented by the Defense Department's Armed Services Board of Contract Appeals (ASBCA). Under the Contract Disputes Act, a contractor appealing a contracting officer's adverse decision on a contract claim may elect to go to the appropriate board of contract appeals, or to the U.S. Court of Federal Claims. Appeals from the boards and from the Court of Federal Claims go to the U.S. Court of Appeals for the Federal Circuit; from there, an appeal can be taken to the U.S. Supreme Court, which may decline review. In modern times, the Supreme Court has heard relatively few cases involving federal procurement.

2941 U.S.C. $\$ 7101$ et seq.; see FAR Subpart 33.2.

30 See generally Kate Manuel, Competition in Federal Contracting: An Overview of the Legal Requirements (Cong. Res. Serv. 2011), available at https://fas.org/sgp/crs/misc/R40516.pdf.

31 See, e.g., Daniel I. Gordon, Bid Protests: The Costs Are Real, but the Benefits Outweigh Them, 42 Pub. Cont. L.J. 489, 490 (2013); James McKay Weitzel Jr., GAO Bid Protest Procedures under the Competition in Contracting Act: Constitutional Implications After Buckley and Chadha, 34 Cath. U. L. Rev. 485, 486-87 (1985).

32 See, e.g., Carl L. Vacketta \& Susan H. Pope, Commercial Item Contracts: When Is A Government Contract Term or Condition Consistent with "Standard" or "Customary" Commercial Practice?, 27 Pub. Cont. L.J. 291 (1998) (discussing statutory history).

33 See Daniel I. Gordon, supra note 31, at 491 (citing statutory authorities).

${ }^{34}$ For an excellent review of the literature on the U.S. procurement system's history, see James F. Nagle, supra note 6, at 579-98. 
inalizing) unauthorized spending, such as the body of laws collectively known as the Antideficiency Act. ${ }^{35}$ The Government Accountability Office (an arm of Congress) has developed extensive rules and precedents, gathered in GAO's Principles of Federal Appropriations Law (also known as the "Red Book" ${ }^{36}$ ), on how appropriations laws should be interpreted and followed. While Article 9 of the UN Convention Against Corruption calls generally for fiscal law controls to check corruption, it appears that few nations have developed fiscal control rules as comprehensive as the United States' - probably because for the U.S. government, fiscal controls are as much about reinforcing democratic structures as they are about stopping corruption.

\section{Access to the Federal Procurement Market}

Access to the federal procurement market can be measured along at least three different vectors: the transparency of the system, the trade agreements that open that market, and the "invisible" barriers that may make it more difficult for firms to join the federal competition. For firms new to the market, access to the federal market is often gained through several steps: subcontracting to experienced prime contractors, then joining an "open" indefinite-delivery/indefinite-quantity (IDIQ) contract (sometimes known as an "open framework" internationally), then moving to more specialized (and less intensely competitive) contracting vehicles. For a firm new to the marketplace (in part because of the obstacles outlined below) it may take several years to move through these stages and gain deep access to federal customers. The firms that succeed in penetrating, however, typically establish stable and lucrative franchises in the federal market, which tends to favor repeat players.

\subsection{Transparency: Opportunities, Awards and the Law}

Those seeking access to the federal market must, of course, first identify opportunities and awards, which are (at least in principle) open and transparent for significant procurements. ${ }^{37}$ Both opportunities and awards must be published on the "Governmentwide Point of Entry" (GPE), at www.fedbizopps.gov. Related documents, such as justifications for other than full-and-open competition, also

\footnotetext{
${ }_{35}$ E.g., 31 U.S.C. $\$ 1351$; see U.S. Accountability Office, The Antideficiency Act, http://www.gao. gov/legal/anti-deficiency-act/about; Matthew H. Solomson, Chad E. Miller \& Wesley A. Demor, Fiscal Matters: An Introduction To Federal Fiscal Law \& Principles.10-7 Briefing Papers 1 (Thomson Reuters, June 2010).

${ }^{36}$ https://www.gao.gov/legal/red-book/overview.

37 See FAR Part 5, Publicizing Contract Actions.
} 
must be published electronically. ${ }^{38}$ Data on federal contract awards, available from the Federal Procurement Data System (FPDS), are now also accessible through a user-friendly website, usaspending.gov - and procurement data should be more readily available in the future, as the federal government implements the "open data" requirements of the Digital Accountability and Transparency Act (DATA) Act of 2014, which calls for better transparency regarding federal expenditures. ${ }^{39}$

There are a number of other federal databases available online which are regularly relied upon in the procurement community. The website www.sam.gov, for example, carries extensive information related to contractor qualification. ${ }^{40}$ Firms that will use IDIQ ("framework") agreements to enter the federal market often will look to databases, such as the Schedules Sales Query database, ${ }^{41}$ published by the sponsoring centralized purchasing agency, the U.S. General Services Administration, in an effort to gain market information. Finally, a number of private firms aggregate and sell data from the federal market.

This is not to say, however, that opportunities and awards in the federal government are uniformly transparent. Data on pending and approved federal purchases through IDIQ ("framework") contracts, for example, are notoriously incomplete. ${ }^{42}$ And data on subcontract awards, which are supposed to be published for first-tier subcontracts, ${ }^{43}$ are widely believed to be only partially reported and published. ${ }^{44}$

Statutes ${ }^{45}$ and regulations $s^{46}$ that govern procurement are published electronically as a matter of course, as are decisions of the boards and courts that hear protests (challenges) and claims stemming from federal contracts. Many changes to federal procurement law originate in statute, and that legislation's progress through Congress can be tracked, relatively transparently, through the website

38 FAR 6.305.

39 Pub. L. No. 113-101, 128 Stat. 1146 (2014).

40 See FAR Part 9.

41 https://ssq.gsa.gov/.

42 See, e.g., Report of the Acquisition Advisory Panel to the Office of Federal Procurement Policy and the United States Congress, ch. 7 (Jan. 2007).

43 FAR 4.1400 ("This subpart implements section 2 of the Federal Funding Accountability and Transparency Act of 2006 (Pub. L. 109-282), as amended by section 6202 of the Government Funding Transparency Act of 2008 (Pub. L. 110-252), which requires contractors to report subcontract award data .... The public may view first-tier subcontract award data at https://www.usaspending. gov.").

44 See, e.g., U.S. Government Accountability Office, Federal Subcontracting: Linking Small Business Subcontractors to Prime Contracts Is Not Feasible Using Current Systems, Report GAO-15-116 (Dec. 2014), http://www.gao.gov/assets/670/667410.pdf.

45 Titles 10 (Armed Forces) and 41 (Public Contracts) of the U.S. Code contain many of the most important provisions regarding federal procurement.

46 The Federal Acquisition Regulation (FAR) is available through www.acquisition.gov/far. The Defense Department supplements to the FAR, which are extensive, are available through a U.S. Air Force-sponsored website, farsite.hill.af.mil. Rules from other federal agencies that affect federal procurement, such as the Small Business Administration, are generally available through the Code of Federal Regulations, available at www.ecfr.gov. 
at www.congress.gov. Statutes and other regulatory initiatives generally must be implemented through the Federal Acquisition Regulation, which constitutes Title 48 of the Code of Federal Regulations, ${ }^{47}$ and proposed and final rules are regularly published through the Federal Register, ${ }^{48}$ the daily administrative journal for the federal government.

\subsection{International Trade Agreements Affording Access}

The transparency of the federal market, outlined above, makes that market practically accessible for vendors from abroad. There is an open question, however, as to whether the legal access assured by the United States' many trade agreements regarding procurement can be enforced. ${ }^{49}$

The starting point in almost any discussion regarding U.S. protectionism is, of course, the Buy American Act, ${ }^{50}$ which was passed in 1933 and now, as implemented, imposes a price preference of 6 or 12 percent (depending on whether small businesses are competing), and even 50 percent (for Defense Department purchases) (which are discussed further below). ${ }^{51}$ The Buy American Act has, however, been largely displaced by the free trade agreements discussed below; as a result, generally only those smaller procurement that fall below the coverage threshold of the GPA and other trade agreements are affected by the Buy American Act.

There are, however, separate domestic preferences - confusingly known as "Buy America" requirements - which limit or bar federal agencies (and, often, their grantees) from purchasing foreign goods and services. ${ }^{52}$ These special "Buy America" restrictions are typically carved out as exemptions from the free trade agreements discussed below, and they impose severe restrictions on the purchase, for example, of foreign trains using federal funds.

The United States has entered into a number of plurilateral, regional and bilateral free trade agreements touching on procurement, probably the most important of which is the World Trade Organization (WTO)'s Agreement on Government Procurement (GPA). ${ }^{53}$ Under the GPA, the federal government and two-thirds of

\footnotetext{
47 www.ecfr.gov.

48 www.federalregister.gov.

49 See, e.g., Christopher R. Yukins \& Steven L. Schooner, Incrementalism: Eroding the Impediments to a Global Public Procurement Market, 38 Geo. J. Int'l L. 529 (2007).

5041 U.S.C. $\$ \$ 8301-8305$.

51 See, e.g., Allen B. Green, International Government Contract Law ch.2 (West. 2016).

52 See, e.g., Kate M. Manuel, Alissa M. Dolan, Brandon J. Murrill, Rodney M. Perry \& Stephen P. Mulligan, Domestic Content Restrictions: The Buy American Act and Complementary Provisions of Federal Law (Cong. Res. Serv., Sept. 12, 2016), available at https://fas.org/sgp/crs/misc/R43354. pdf.

53 See generally Sue Arrowsmith, Government Procurement in the WTO (Kluwer Law Int'l 2003) (extensive background and literature regarding free trade agreements in procurement).
} 
the U.S. states guarantee at least some access to their procurement markets. The U.S. Defense Department has also entered into reciprocal defense procurement agreements with the ministries of defense in a number of allied countries; those agreements, codified in the Defense Federal Acquisition Regulations Supplement (DFARS), generally guarantee non-discriminatory access to each partner's market for defense materiel and services. But while access under the GPA and other free trade agreements has been codified in the Federal Acquisition Regulation and its supplements, ${ }^{54}$ and so access is generally honored as a matter of practice in the federal acquisition process, there are legal and practical barriers to any foreign vendor that seeks to enforce access under trade agreements. ${ }^{55}$ In sum, foreign vendors' access to the public procurement markets in the United States is far from assured, as a legal matter.

\subsection{Other Barriers to Access}

There are other barriers, some quite formidable, to access in the federal procurement market. One of the most serious is the small business preference imposed by law; under that statute, roughly one quarter of federal procurement is targeted for small businesses. ${ }^{56}$ Although eligible small businesses can, in principle, be affiliates of foreign firms, so long as they are based in the United States and contribute to the U.S. economy, ${ }^{57}$ in practice it may be very difficult for a firm with ties abroad to qualify as a small business. Taken together, these U.S. small business preferences can work a substantial barrier to entry.

Other regulatory requirements can also raise barriers to entry, both for foreign firms and for domestic companies. The cybersecurity requirements imposed on information technology purchased by the federal government, for example, can in practice exclude foreign firms, because while European firms are more likely to follow standards more broadly adopted in the European Union, U.S. firms are to follow the cybersecurity standards published by the National Institutes of Standards and Technology (NIST), which have been adopted by the federal government in its procurement..$^{58}$ These types of practical and legal barriers can be mitigated, however, when vendors challenge restrictive requirements, either

\footnotetext{
54 See FAR Part 25; DFARS Part 225.

55 See, e.g., Christopher R. Yukins, International Procurement Developments in 2016-Part I: The Trump Administration's Policy Options in International Procurement, 2017 Gov't Con. Year in Rev. Br. 3 (discussing Per Aarsleff decisions).

56 https://www.sba.gov/contracting/contracting-officials/goaling.

57 See, e.g., Size Appeal of Global Submit, Inc., SBA No. SIZ-5804, 2017 WL 461190 (SBA OHA, Jan. $18,2017)$.

58 See, e.g., Erik Puskar, The Benefits of U.S.-European Security Standardization (NIST 2012), available at http://dx.doi.org/10.6028/NIST.IR.7861.
} 
formally through a bid challenge process ${ }^{59}$ or informally, for example through the internal adjudicative process called for by the Defense Department to reconcile differing cybersecurity standards. ${ }^{60}$

It should be emphasized, however, that the sheer bulk of federal procurement regulations - which run to thousands of pages - itself works a barrier to access. Reformers have often recommended reducing the regulatory bulk, to lower costs for business and to minimize barriers to entry. ${ }^{61}$ Practically speaking, however, there are strong countervailing forces, whether born of inertia or bureaucratic self-interest, that resist any wholescale dismantling of what is, in fact, a startlingly complex regulatory regime.

\section{Leading Procurement Methods in Federal Procurement}

To understand the procurement methods used most commonly in the federal procurement system, it is probably best to put them in historical context, and to see these methods not in isolation but as part of a broader system. As the discussion above reflected, at first procurement in the Revolutionary War was done, on the colonies' side, largely through a commissary system run by merchants who received commissions for provisioning the Continental Army. ${ }^{62}$ That eventually matured into a more modern "contract" system, in which vendors bid for contract awards on what was generally a sealed-bid, low-price system. ${ }^{63}$ The discussion below recounts how that sealed bidding system in time gave way to broad use of multilateral competitive negotiations, which is turn was (by the end of the twentieth century) complemented by "catalog" contracts (known as "indefinite-delivery/indefinite-quantity" (IDIQ) contracts in the U.S. system, and "frameworks agreements" in other countries). These changes were driven by technological advances and market shifts, both inside and outside the government, and by a desire to make procurement more efficient and to achieve better value.

\footnotetext{
59 U.S. Government Accountability Office, Bid Protests at GAO: A Descriptive Guide 8 (9 $9^{\text {th }}$ ed. 2009) ("Although most protests challenge the acceptance or rejection of a bid or proposal and the award or proposed award of a contract, GAO considers protests of defective solicitations (e.g., allegedly restrictive specifications ...."), available at https://www.gao.gov/assets/210/203631.pdf.

60 See DFARS.252.204-7008.

61 See, e.g., Advisory Panel on Streamlining and Codifying Acquisition Regulations, Supplement to the Section 809 Panel Interim Report (May 2017), available at www.section809panel.org.

62 See James F. Nagle, supra note 6, at 28.

${ }_{63}$ Id. at 48; Clifton E. Mack, supra note 4, at 9.
} 


\subsection{Sealed Bidding}

Sealed bidding is today governed by Part 14 of the Federal Acquisition Regulation, and though it has been largely superseded by competitive negotiations (discussed below), it is still used regularly for procurements with already-detailed specifications, such as construction projects. Consistent with best practices internationally, invitations for sealed bids must describe the government's requirements clearly, and unnecessarily restrictive specifications, or requirements that might unduly limit the number of bidders, are not allowed. ${ }^{64}$ (Unlike the practice under the European procurement directives, it is not common to engage in "restricted tendering" - in other words, in U.S. federal procurement, it is not common for the agency to use an early qualification process to limit the number of vendors allowed to bid. ${ }^{65}$ ) Contracting officers are personally responsible for reviewing the invitation, before publication, to ensure that it does not unnecessarily impair competition. $^{66}$

Invitations for bids are generally to be prepared using a standard format set forth in the Federal Acquisition Regulation (FAR). ${ }^{67}$ Invitations for bids must be publicized appropriately, ${ }^{68}$ allowing vendors reasonable time to prepare their bids, ${ }^{69}$ and then vendors must submit their sealed bids by the time, and at the place, specified by the invitation. Invitations to bid may be amended, so long as all bidders are given notice of the amendment, ${ }^{70}$ and invitations may be cancelled before bids are opened, but only if cancellation is "clearly in the public interest." 71 Bids are to be opened publicly, and are to be evaluated without discussions (which are the hallmark of competitive negotiations, discussed below). ${ }^{72}$

Under sealed bidding, award is to be made to "that responsible bidder" (a concept discussed more below) "whose bid, conforming to the invitation for bids, will be most advantageous to the Government, considering only price and the price-related factors included in the invitation." 73 "Price-related factors" may include foreseeable costs, such as transportation costs, or price adjustments to foreign bids due to the Buy American Act's price preference. ${ }^{74}$

While sealed bidding declined in importance in the latter half of the twentieth

64 FAR 14.101.

65 See FAR 9.202 (procedural requirements that must be met before list of qualified suppliers can be prepared).

66 FAR 14.202-6.

67 FAR 14.201-1(a).

68 FAR 14.203-2 (citing FAR Part 5 provisions regarding publication).

69 FAR 14.202-1.

70 FAR 14.208.

71 FAR 14.209.

72 FAR 14.101(d).

73 FAR 14.101(e).

74 FAR 14.201-8; see FAR 25.105 (Buy American Act price preference). 
century, electronic reverse auctions - conceptually, the successor to traditional bidding methods - gained in prominence in federal procurement, though the use of electronic auctions remained relatively limited. ${ }^{75}$ While traditional tendering procedures contemplate a single set of bids, opened simultaneously, electronic reverse auctions extend that concept and allow multiple competing bids, as vendors compete to offer successively lower prices in an effort to win the award. The FAR notably does not regulate reverse auctions, though the European procurement directives ${ }^{76}$ and many other procurement regimes around the world do. ${ }^{77}$ Perhaps because of the lack of regulation, reverse auctions in the United States have been criticized, in some cases, for not providing robust competition. ${ }^{78}$

\subsection{Multilateral Competitive Negotiations}

As discussed above, sealed bidding (akin to "open tendering" abroad) dominated federal procurement until the twentieth century, when multilateral competitive negotiations became much more important. Traditionally, in times of war the federal government had put sealed bidding aside in favor of negotiated contracts, to speed mobilization. ${ }^{79}$ That process expanded through the twentieth century, as the federal government embraced multilateral competitive negotiations as a favored procurement method. This shift to competitive negotiations reflected the federal government's increasing reliance on the private sector for cutting-edge technology, for example in weapons and information technology systems. ${ }^{80}$ To ensure access to the latest technology, the government shifted from sealed bidding - which might give the government the lowest price, but on a solution specified by the government - to multilateral negotiations which allowed different vendors to compete by presenting diverse solutions, and which allowed the government to interrogate vendors on the merits of their respective solutions.

The following table, from a compilation prepared by Umer Chaudhry using data published in the Federal Procurement Data System, shows that by fiscal year 2014, competitive negotiations (referred to as "Negotiated Proposals") were the

\footnotetext{
75 See, e.g., U.S. Government Accountability Office, Reverse Auctions: Guidance Is Needed to Maximize Competition and Achieve Cost Savings, Report No. GAO-14-108 (Dec. 9, 2013), available at http:// www.gao.gov/products/GAO-14-108.

76 See EU Directive 2014/24/EU, art. 25.

77 UNCITRAL Model Law on Public Procurement, ch. 6 (2011), available at http://www.uncitral.org/ pdf/english/texts/procurem/ml-procurement-2011/2011-Model-Law-on-Public-Procurement-e.pdf.

78 See, e.g., Danielle Ivory, "Reverse Auctions" Draw Scrutiny, NY Times, Apr. 6, 2014, available at https://www.nytimes.com/2014/04/07/business/reverse-auctions-draw-scrutiny.html.

79 See, e.g., James Nagle, supra note 6, at 415.

80 See, e.g., Curtis Lee Coy, The Competition in Contracting Act of 1984, at 24-26 (Navy Postgraduate School, June 1986) (citing authorities), available at https://archive.org/stream/competitionincon00coyc/competitionincon00_oyc_djvu.txt.
} 
leading method of procurement in the federal government; the percentages are of total awards, by dollars:

\section{Solicitation Procedures Fiscal Year 2014: U.S. Government Procurement}

Methods

Negotiated Proposals:

$38.64 \%$

Single Source Solicited:

$28.68 \%$

Subject to Multiple Award Fair Opportunity:

$21.42 \%$

Simplified Acquisition:

$4.27 \%$

None:

$2.27 \%$

Sealed Bid:

$2.06 \%$

Two Step:

Basic Research:

$0.88 \%$

Architect - Engineer:

$0.42 \%$

No Solicitation Procedure Reported

Alternative Sources:

$0.13 \%$

Program Solicitation:

$0.09 \%$

Broad Agency Announcement:

$0.00 \%$

Simplified Acquisition Procedures-Non-Competitive:

$0.00 \%$

Total

$100.00 \%$

The percentage of awards attributable to competitive negotiations ("Negotiated Proposals"), roughly 39\%, far exceeded those awards made using sealed bidding, of roughly $2 \%$. Moreover, over $21 \%$ of the awards were made through second-stage competitions under IDIQ contracts ("framework" agreements) (listed above as awards "Subject to Multiple Award Fair Opportunity"). Those second-stage competitions, amongst catalog contract holders, often carry many of the attributes of competitive negotiations. ${ }^{81}$ Taken together, the awards made by competitive negotiations and second-stage competitions amounted to roughly $60 \%$ of all federal awards, by dollar amount.

Competitive negotiations are governed by Part 15 of the FAR, and those rules were subject to a major "rewrite" during the Clinton administration, ${ }^{82}$ under then-Administrator of the Office of Federal Procurement Policy Steven Kelman (who took time away from his long tenure as a professor at Harvard University's John F. Kennedy School of Government). Although the threat of bid challenges (called "protests" in the U.S. system) left contracting officials reluctant, even after

${ }_{81}$ Cf. Vernon J. Edwards, Competitive Processes in Government Contracting: The FAR Part 15 Process Model and Process Inefficiency (Apr. 2003) (criticizing use of full competitive procedures in second-stage awards under standing catalog contracts), available at http://www.wifcon.com/anal/ analcomproc.htm.

${ }^{82}$ The final rule embodying the "rewrite" is at 62 Fed. Reg. 51224 (Sept. 30, 1997), available at https:// www.gpo.gov/fdsys/pkg/FR-1997-09-30/pdf/97-25666.pdf. 
the "rewrite," to use the full panoply of information-gathering tools available under FAR Part $15,{ }^{83}$ competitive negotiations play a critical role in enabling complex federal procurements.

Under the rules, the procedures at FAR Part 15, Contracting by Negotiation, may be used for both sole-source and competitive negotiations. ${ }^{84}$ In practice, however, because of the strong bias against sole-source contracting in federal procurement ${ }^{85}$ competitive negotiations are the norm.

FAR Part 15 contemplates different source selection approaches, depending on the nature of the negotiated acquisition. While both of the basic approaches assume a search for "best value" - a weighing of price and quality against each other - the approaches can vary radically. Where the requirement is "clearly definable and the risk of unsuccessful performance is minimal," the FAR calls for making cost or price a dominant role in the award. In that case, a "lowest price technically acceptable" (LPTA)-type award may be made, to the technically acceptable proposal with the lowest evaluated price. ${ }^{86}$ In practice, an LPTA procedure differs materially from a traditional sealed bidding procedure in one important respect: under the LPTA procedure, the agency may engage in exchanges of information with the offerors, ${ }^{87}$ which mitigates the risk that the agency will make an error during the acquisition.

Alternatively, the agency may engage in a "tradeoff process," where it is in the government's interest "to consider award to other than the lowest priced offeror or other than the highest technically rated offeror." ${ }^{\text {" }}$ The evaluation factors to be used in the tradeoff for award - both evaluation factors and significant subfactors - must be set forth in the solicitation, and the factors' "relative importance must be clearly stated in the solicitation." ${ }^{9}$ These requirements parallel those of the European procurement directive ${ }^{90}$ and the UNCITRAL model law. ${ }^{91}$

\footnotetext{
83 See, e.g., David A. Whiteford, Negotiated Procurements: Squandering the Benefit of the Bargain, 32 Pub. Cont. L.J. 509 (2003). In 2011, then-Administrator of the Office of Federal Procurement Policy Daniel Gordon (who subsequently served as an associate dean in GWU's procurement law program) issued his well-known "myth-buster" memorandum, https://obamawhitehouse.archives. gov/sites/default/files/omb/procurement/memo/Myth-Busting.pdf, which encouraged contracting officials to engage more broadly with industry in the acquisition process, under the authorities created by FAR Part 15 .

${ }^{84}$ FAR 15.002.

85 See FAR Subpart 6.3 (procedural requirements that must be met before employing other than fulland-open competition).

86 FAR 15.101-2.

87 FAR 15.101-2(b)(4).

${ }^{88}$ FAR 15.101(a).

89 FAR 15.101-1(b)(1).

${ }^{90}$ EU Directive 2014/24/EU, Recital (45).

91 UNCITRAL Model Law on Public Procurement, supra note 77, Art. 11(5) (c) (solicitation must set forth the "relative weights of all evaluation criteria").
} 
As in other systems ${ }^{92}$ the U.S. rule structure leaves the procuring federal agency with flexibility in weighing the various factors during the evaluation process. This flexibility presumably comes because if contracting officials' discretion is bound too tightly by the solicitation's evaluation factors - if, for example, award in a competitive negotiation must be based upon a rigid formula, as is sometimes suggested in other procurement regimes - that rigid loss of discretion would rob officials' of their ability to consider, and weigh, new and innovative solutions put forward by offerors. The GAO has said that an agency's source selection authority (the deciding official, in the U.S. system) may not make an award decision based solely upon a mechanical formula set forth in the solicitation. ${ }^{93}$ These GAO rulings, part of a pattern of bid challenge decisions, ${ }^{94}$ offered an important lesson: although it is tempting to bind the awarding official to a predetermined formula so as to reduce the risk of corruption, robbing that official of all discretion in the evaluation will, in essence, strip the competitive evaluation of much of its value, and return the agency to the days of sealed bidding/open tendering when award was made based upon rigid criteria defined before the government entered the rich diversity of the marketplace.

To access that market information, FAR Part 15 affords the government a number of ways to engage with vendors: through meetings and exchanges during the acquisition planning process, ${ }^{95}$ through written exchanges and negotiations, ${ }^{96}$ and through oral presentations (though those are optional) and debriefings after award. The debriefings are, at their core, intended to help vendors prepare better offers in later competitions. (Notably, both the winner and the losers are entitled to request debriefings.) As a practical matter, however, debriefings also play a pivotal role in bid protests (discussed further below): agencies hope that thorough debriefings will dissuade disappointed offerors from protesting, and a protester often will rely closely on the information disclosed in a debriefing to argue that the award was flawed.

92 See, e.g., Guide to Enactment of the UNCITRAL Model Law on Public Procurement 196 (2012) (Model Law "contains detailed rules regulating the procedures ... which are designed to include safeguards against possible abuses or improper use of this method and robust controls. Nonetheless, they also preserve the necessary flexibility and discretion on the part of the procuring entity in the use of the method, without which the benefits of the procedure disappear."), available at http:// www.uncitral.org/pdf/english/texts/procurem/ml-procurement-2011/Guide-Enactment-Model-Law-Public-Procurement-e.pdf.

${ }_{93}$ E.g., C \& B Constr., Inc., Comp. Gen. B-401988.2, 2010 CPD 1 (Jan. 6, 2010) (sustaining protest because contemporaneous evaluation record consisted merely of numerical scores assigned to each vendor's quotation, and lacked any information to show a basis for those scores, or a reasoned basis for any tradeoff judgments made in the source selection).

94 See Formation of Government Contracts, supra note 12, at 678-69 (reviewing authorities).

${ }^{95}$ FAR 15.201.

${ }_{96}$ As noted, see supra text accompanying note 83 , too often contracting officials will stop short of open exchanges with vendors because of a fear that those discussions may trigger a bid challenge. 


\section{3 "Catalog" Contracts/Framework Agreements: Indefinite- Delivery/Indefinite Quantity (IDIQ) Contracting}

As the discussion above explained, competitive negotiations came to dominate federal procurement by the late twentieth century. In the 1990s, however, and partly as a result of enabling legislation in the Federal Acquisition Streamlining Act of 1994, a different contracting method - known most commonly in the U.S. federal system as "indefinite-delivery/indefinite-quantity" (IDIQ) contracting came to the front ranks of federal contracting methods.

This method is commonly referred to as "catalog" contracting, as contractors will typically agree to sell an array of goods and services to the government under a master catalog contract, known as a "framework agreement" in other jurisdictions (such as the European Union). The master catalog contract generally will set forth ceiling unit prices; when the contracting agency (or another user agency) orders from the master contract, however, the ordering agency may negotiate lower prices, sometimes by running a "mini-competition" 97 among the contract holders. The government originally may award only a small, fixed number of master contracts (known as a "closed" framework under the UNCITRAL model law), ${ }^{98}$ or may allow additional vendors to join the arrangement over time (an "open" framework). How the arrangement is structured - for example, how long the master catalog contracts are valid, how many vendors hold master contracts, and how orders under those master contracts are notified and competed ${ }^{99}$ - can have profound impacts on the success of the contracting method.

There are two different types of catalog contracts in the U.S. federal system, the Multiple Award Schedules (MAS) contracts administered by the U.S. General Services Administration (GSA) under FAR Part 8, and the IDIQ contracts run by other agencies (typically purchasing agencies providing centralized services to other user agencies) under FAR Subpart 16.5. The two regimes differ in small but important ways, for example in the notice and transparency regarding opportunities and awards, in the extent of competition, and in whether awarded orders can be protested (what abroad might be called challenges to "framework contracts" under standing framework agreements). ${ }^{100}$

\footnotetext{
${ }_{97}$ The term is British, though the concept applies equally well to processes in the United States. See, e.g., UK Department of Education, Run a mini-competition between suppliers on a framework, https://www.gov.uk/guidance/buying-for-schools/3b-run-a-mini-competition-between-supplierson-a-framework.

98 UNCITRAL Model Law on Public Procurement, supra note 77, Art. 2(3)(ii) (“'Closed framework agreement' means a framework agreement to which no supplier or contractor that is not initially a party to the framework agreement may subsequently become a party.").

99 See generally Gian Luigi Albano \& Caroline Nicholas, The Law and Economics of Framework Agreements (Cambridge U. Press 2016).

${ }^{100}$ See FAR Subpart 8.4 (GSA MAS contracts); FAR Subpart 16.5 (IDIQ contracts).
} 
Probably the most important difference between IDIQ contracts and the GSA Multiple Award Schedule contracts is how they control for price. Unlike "closed" IDIQ contracts, which force vendors to compete to join, as noted the GSA MAS contracts are "open" frameworks - they are standing catalog contracts, and new contractors can apply to join at any time. As a result, it is very difficult to use competition between contractors to control price or quality as contractors join the standing arrangements, for it would be difficult to demand competition from such potentially disparate vendors and still maintain a robust and efficient open framework. The GSA MAS contracts therefore harness competitive forces outside the government marketplace, in the commercial marketplace, to control prices: under a "most favored customer" provision known as the "Price Reductions Clause," MAS contractors must vow to reduce their MAS prices if they reduce their commercial prices. Although GSA has announced that in the future it intends to rely more on prices paid data and less on this most favored customer strategy $y^{102}$ - among other things, a most favored customer commitment creates onerous fraud risks for contractors ${ }^{103}$ - the clause highlights the special challenges raised by an "open” framework agreement, such as GSA's MAS contracts.

\section{Types of Contracts: Fixed-Price and Cost-Reimbursement}

In the U.S. federal system, there are two basic types of contracts: fixed-price and cost-based ${ }^{104}$ Fixed-price contracts (which include firm-fixed-price ("turnkey" or "complete solution") contracts, and fixed-price contract with economic price adjustments (for inflation, for example)) are much like contracts in other procurement markets around the world. Importantly, all federal contracts for commercial items under FAR Part 12 - a substantial portion of the market - are required to be fixed-price contracts. ${ }^{105}$

Cost-reimbursement contracts, in contrast, are typically used for riskier projects, because the government presumptively absorbs much of the cost and performance risks. The federal government's well-established system for cost-reimbursement contracting arguably gives the United States a strategic advantage, for

\footnotetext{
${ }^{101}$ GSAR 552.238-75 - Price Reductions.

102 See U.S. General Services Administration, GSA Acquisition Rule Captures Transactional Data, Drives Savings and Eliminates Burdensome Reporting, available at https://www.gsa.gov/portal/content/137210.

103 See, e.g., Aaron Woodward, The Perverse Effect of the Multiple Award Schedules' Price Reductions Clause, 41 Pub. Cont. L.J. 527 (2012); Multiple Award Schedule Advisory Panel Final Report 5 (Feb. 2010) (distinguished agency/stakeholder panel, noting that Price Reduction Clause is not effective), available at https://www.gsa.gov/graphics/staffoffices/MAS_Panel_Final_Report_Signatures.pdf.

${ }^{104}$ See Formation of Government Contracts, supra note 12, ch. 9.

${ }^{105}$ FAR 12.207.
} 
the mature cost-reimbursement system allows the U.S. government to undertake much riskier initiatives in developing, for example, new weapons or vehicles for space exploration. While cost-reimbursement contracts are less common, they constitute an important subset of the federal market: many of the largest contracts, for weapons development for example, are done on a cost-reimbursement basis, and often only the larger and more sophisticated contractors have the necessary accounting systems and controls in place to handle the complex rules and procedures of cost-reimbursement contracting. ${ }^{106} \mathrm{New}$ entrants to the market, such as emerging information technology contractors and foreign vendors, are far less likely to undertake a cost-reimbursement contract.

\section{Challenges to Procurement: Bid Protests in the Federal System}

Over the past few decades, through international trade agreements and other channels, the United States has pressed other nations to adopt systems for bid challenges (known as "bid protests" in the U.S. federal system). The WTO Agreement on Government Procurement (GPA) requires that members have a bid challenge system in place, ${ }^{107}$ and the UN Convention Against Corruption (which has been adopted by most nations) specifically calls in Article 9 for an "effective" system of domestic review, including an effective system of appeal, in each member nation. ${ }^{108}$

Under the U.S. system, which is very similar to remedies systems now in place in many nations, ${ }^{109}$ prospective bidders and offerors may challenge flawed solicitations before the time set for the submission of bids or proposals, and after award the disappointed bidders or offerors may challenge flaws in the award process. Although bid protests can be controversial - protests raise costs and delays, and often make the relationship between bidders and government officials more adversarial - protests have proven an essential means of holding officials accountable for failures in the procurement system, and thus for preserving the public legitimacy of the procurement system.

In the U.S. system (as in many other systems elsewhere in the world), pro-

\footnotetext{
106 See FAR 16.301-3.

${ }^{107}$ See, e.g., Xinglin Zhang, Constructing a System of Challenge Procedures to Comply with the Agreement on Government Procurement, in The WTO Regime on Government Procurement: Challenge and Reform 483 (Sue Arrowsmith \& Robert Anderson, eds., Cambridge U. Press 2011).

${ }^{108}$ UN Convention Against Corruption (UNCAC), Art. 9, https://www.unodc.org/unodc/en/treaties/ $\mathrm{CAC} /$.

${ }^{109}$ See, e.g., OECD, Public Procurement Review and Remedies Systems in the European Union, SIGMA Papers, No. 41 (OECD Publishing, Paris, 2007), available at http://dx.doi.org/10.1787/5km160q9vklt-en.
} 
tests can be brought in any one of three different forums: in the contracting agency itself, at an independent agency charged with hearing bid protests (the U.S. Government Accountability Office (GAO)), or in court (at the U.S. Court of Federal Claims). As noted, in any of the three forums, a protest regarding the terms of a solicitation (regarding unreasonably restrictive specifications, for example) generally must be brought before bids or proposals are due. ${ }^{110}$ The deadlines for post-award protests are more complicated: at the procuring agency and at GAO, a post-award protest must be brought within 10 days of when the protester knew or should have known of the grounds for protest, ${ }^{111}$ though that period can be extended for several days at the GAO if the protester requests, and receives, a debriefing. ${ }^{12}$ At the Court of Federal Claims, in contrast, there is no fixed deadline for submission of post-award protests. ${ }^{113}$

Procedures at the three forums also vary widely. In an agency-level protest, brought at the contracting agency itself, the protester generally requests that the agency shift the review to a level above the contracting officer, in an effort to ensure at least some measure of independence. ${ }^{114}$ The agency need not provide the protester with the administrative record, however, nor allow the protester an opportunity to probe the agency's failures. As a result of these and other procedural constraints, agency-level protests are generally viewed with disfavor by vendors, and are relatively seldom used.

Procedures at the primary forum used - GAO - are more complex. After the protest is filed, the agency report relating to the protest grounds must be produced within 30 days, with the relevant administrative record. ${ }^{115}$ The protester and the intervenor (the awardee) generally have ten days to respond, and if the administrative record reveals new grounds for protest, the protester may supplement its original grounds of protest. ${ }^{116}$ The protester must show that the protested error prejudiced the protester - caused the protester to lose the award, in other words - in order to prevail. ${ }^{117}$ While only a relatively small percentage of federal awards are protested at GAO every year, and the percentage of successful protests that result in an eventual award is even smaller, the prospect of an adverse GAO

\footnotetext{
${ }_{110}$ E.g., FAR 33.103(e).

${ }^{111}$ See, e.g., FAR 33.103(e); 4 C.F.R. $\$ 21.2$ (GAO bid protest rule).

1124 C.F.R. $\$ 21.2$.

113 See, e.g., U.S. Court of Federal Claims Rules, App. C, Procedure in Procurement Protest Cases Pursuant to 28 U.S.C. S 1491(b); Raymond M. Saunders \& Patrick Butlera, A Timely Reform: Impose Timeliness Rules for Filing Bid Protests at the Court of Federal Claims, 39 Pub. Cont. L.J. 539 (2010).

${ }^{114}$ FAR 33.103(d)(4).

1154 C.F.R. $\$ 21.3$.

116 See GAO, Bid Protests at GAO: A Descriptive Guide, http://www.gao.gov/decisions/bidpro/bid/filing. html.

117 See Formation of Government Contracts, supra note 12, at 1735-40.
} 
decision drives many agencies to act more deliberately, and to take corrective action promptly when a strong protest emerges. ${ }^{118}$

Although GAO is by far the most popular bid protest forum and is generally acknowledged as the leading authority on issues of federal contract formation, ${ }^{119}$ the U.S. Court of Federal Claims offers an alternative bid protest forum - and a possible line of second, largely de novo review, should the GAO rule in the first instance against the protest. Bid protests at the Court of Federal Claims' are not limited to 100 days, as they are at the GAO, and the sometimes more expansive process at the Court of Federal Claims can make protests more costly to litigate; this helps explain vendors' preference for the GAO. By the same token, though, the judges of the Court of Federal Claims, and on appeal the U.S. Court of Appeals for the Federal Circuit (or even the Supreme Court) may allow more probing discovery of the agency, and may be willing to apply a more demanding standard of review or develop new doctrine - outcomes that may not be possible at the GAO, which tends to apply a conservative standard of review, and which offers no formal right of appeal. As a result, protesters will sometimes bring more difficult cases directly to the Court of Federal Claims.

Unlike protest forums in other nations, which may provide much broader relief (even lost profits) to a party wrongfully denied an award, post-award relief for a successful protester in the U.S. forums tends to be much more circumscribed: generally minimal attorney fees, the bid and proposal costs incurred by the protester, and a direction (or recommendation, in the case of GAO) that the competition be corrected and reopened. While these may seem a paltry reward in comparison to the costs of bringing a bid protest, and of antagonizing an agency customer, the flexible utility of protests - including, importantly, the ability of agencies to resolve a strong protest by taking immediate corrective action - makes them an enduring, and important, part of the federal procurement system.

\section{Anti-Corruption Measures}

Beyond the bid challenge system outlined above, the federal government has evolved a substantial array of additional anti-corruption strategies and institutions. Two important aspects of these anti-corruption measures bear special mention. First, these anti-corruption measures are not directed solely at what one might call corruption in the traditional sense, such as bribes and gratuities. Instead,

\footnotetext{
118 See generally Moshe Schwartz \& Kate M. Manuel, GAO Bid Protests: Trends and Analysis (Cong. Res. Serv. July 21, 2015), https://fas.org/sgp/crs/misc/R40227.pdf.

119 See, e.g., Michael J. Schaengold, T. Michael Guiffré \& Elizabeth M. Gill, Choice of Forum for Federal Government Contract Bid Protests, 18 Fed. Circuit B.J. 243 (2009) (discussion of the three bid protest forums, with statistics), available at http://cfcbar.org/upload/2009-Choice-of-Forum-for-FederalGovernment-Contract-Bid-Protests.pdf.
} 
these anti-corruption measures in the federal government - which track similar measures in governments around the world - generally address a broader range of failures in the procurement system, from bribery to indifference in contracting officials. They are, in other words, broadly aimed at failures arguably inherent to any system that entrusts purchasing to an agent, and performance to a profit-seeking contractor. ${ }^{120}$

Second, the various federal anti-corruption instruments (some of which are discussed below) are not well-coordinated - a prosecutor investigating a contractor's bribe, for example, may fail to coordinate in any effective way with other enforcement officials proceeding against the contractor. While this seems disorganized, the lack of coordination means that a contractor that decides to indulge in corruption faces a much more variegated legal risk - one that is difficult to assess, and probably impossible to control.

\subsection{Criminal Sanctions}

Although most of the traditional criminal bars against corruption ${ }^{121}$ - against bribery and gratuities, for example, and against unlawful conflicts of interest - are lodged in Title 18 of the U.S. Code, there are notable exceptions. For example, both the Procurement Integrity Act ${ }^{122}$ (which imposes criminal sanctions for "leaking" bid or proposal information) and the Anti-Kickback Act ${ }^{123}$ (which punishes commercial bribery between prime contractors and subcontractors) are lodged in Title 41, the general public contracts code.

\subsection{Ethics}

The ethics codes in the U.S. procurement system are generally rigorously honored and enforced, ${ }^{124}$ and those ethics codes are tightly integrated with criminal sanctions. Under 18 U.S.C. $\$ 208$, for example, personal conflicts of interest in seeking employment may trigger criminal sanctions unless the activity at issue is permitted by ethics regulations published by the U.S. Office of Government

${ }^{120}$ See, e.g., Peter Trepte, Regulating Procurement, ch. 2.3 (Oxford U. Press 2004) (discussing principal-agent theory in procurement): Albert Sanchez Graells, Public Procurement and the EU Competition Rules 56-57 \& n.58 (Hart Publishing, 2d ed. 2015) (canvassing literature on agency theory); Christopher R. Yukins, A Versatile Prism: Assessing Procurement Law Through the Principal-Agent Model, 40 Pub. Cont. L. J. 63 (2010), available at http://scholarship.law.gwu.edu/faculty_publications/996/.

121 See Formation of Government Contracts, supra note 12, at 148-219.

12241 U.S.C. ch. 21.

12341 U.S.C. $\$ 51$ et seq.

${ }^{124}$ See generally Jessica Tillipman, Gifts, Hospitality and the Government Contractor, 14-7 Briefing Pap. 1 (Thomson Reuters/West June 2014). The U.S. Office of Government Ethics (OGE) maintains an excellent resource website on ethics laws and rules, at www.oge.gov. 
Ethics (OGE), and under 18 U.S.C. $\$ 207$, the director of the OGE may waive certain employment restrictions. The ethics rules, in other words, can provide a safe harbor from criminal prosecution, and the ethics regime works hand-in-hand with the harsher criminal sanctions. Nor is the ethics regime unidimensional: while the general ethics rules administered by the OGE apply to all executive branch employees, an additional layer of stricter rules applies under the Procurement Integrity Act (discussed above) to senior procurement officials. ${ }^{125}$

\subsection{Corporate Compliance}

The ethics regime discussed above is relevant far beyond government, for in many ways it receives "mirror" enforcement in the contractor community, under the compliance systems required by the FAR. ${ }^{126}$ Corporate compliance, which previously launched in the U.S. private sector under the U.S. Sentencing Commission's organizational sentencing guidelines, in 2008 became a standard part of federal contracting. ${ }^{127}$ While contractor "self-cleaning" under Article 57 of the European procurement directive 2014/24/EU is to occur after a bad act has occurred, as the contractor seeks to redeem itself, ${ }^{128}$ under the U.S. system a contractor is required constantly to "clean" itself - to implement and enforce a vigorous system of compliance as soon as it becomes a significant contractor. ${ }^{129}$ As part of that constant "cleansing" under the corporate compliance rules, a contractor is required to implement internal rules that mirror the government's ethics rules. Thus, for example, because federal gift rules are generally triggered for gifts over $\$ 20$, or for cumulative annual gifts over $\$ 50$ from one source, ${ }^{130}$ a contractor code of conduct - an essential part of any compliance system - may instruct the contractor's employees to coordinate and limit their gifts to individual government officials in accordance with these strict rules.

\subsection{Debarment}

Corporate "self-cleaning," as it is called in Europe, also plays a pivotal role in debarment (exclusion) in the U.S. system. By law, debarment is not to be a punishment; ${ }^{131}$ instead, it is a means for federal agencies to exclude contractors that

\footnotetext{
125 See FAR 3.104-3.

126 See FAR 52.203-13 (clause) and FAR Subpart 9.4 (debarment standards).

127 See 73 Fed. Reg. 67064 (Nov. 12, 2008) (final rule).

${ }^{128}$ See, e.g., Sue Arrowsmith, The Law of Public and Utilities Procurement: Regulation in the EU and UK 1271-72 (Sweet \& Maxwell/Thomson Reuters 3d ed. 2014).

129 See FAR 52.203-13; FAR 3.1004(a).

1305 C.F.R. $\$ 2635.204$. See generally The Standards of Ethical Conduct for Employees of the Executive Branch, 5 C.F.R. Part 2635.

131 See FAR 9.402(b) ("The serious nature of debarment and suspension requires that these sanctions
} 
pose particular risks, such as reputational or performance risks. Unlike the World Bank's sanctions system, which is rigidly adjudicative, the U.S. system is highly flexible. Thus, though the contractor facing debarment is entitled to a hearing before the agency suspending and debarring official (SDO), ${ }^{132}$ that hearing is in practice a very flexible event, and the SDO may use the opportunity not for fact-finding but rather to press the contractor to adopt more aggressive internal controls, which in turn may be reflected in an administrative agreement between the agency and the contractor. Suspension and debarment in the U.S. system are, in sum, tools of risk mitigation, not a sanctions regime to punish wayward contractors.

\subsection{Civil Society and Legislative Oversight}

Both civil society and Congress play active roles in overseeing the procurement system, to ensure its integrity. Members of civil society - journalists, various nonprofit organizations and academics, for example - have gained greater insight into the federal procurement system as that system has grown more transparent. Their access is likely to deepen in the coming years, as principles of "open government" are implemented in the federal government, through reforms such as the DATA Act, which requires greater transparency regarding the government's expenditures. ${ }^{133}$ At the same time, Congress will continue to play an important role in day-to-day oversight. Notably, some of the largest scandals of recent years were unearthed, at least in part, through congressional oversight. Senator John McCain (R-AZ) and his staff, for example, were among the first to unearth disturbing evidence that Darleen Druyun, one of the leading Air Force procurement officials of her time, was tangled in an illegal conflict of interest with contractor Boeing. ${ }^{134}$ Although congressional oversight is typically most intense when the White House and Congress are controlled by different political parties, procurement policy is, at its heart, not a partisan issue, and Congress' oversight and reform initiatives are, as noted, central elements of the U.S. procurement system.

\footnotetext{
be imposed only in the public interest for the Government's protection and not for purposes of punishment.").

132 See, e.g., FAR 9.406-3(b)(2) ("In actions not based upon a conviction or civil judgment, if it is found that the contractor's submission in opposition raises a genuine dispute over facts material to the proposed debarment, agencies shall also ... [a]fford the contractor an opportunity to appear with counsel, submit documentary evidence, present witnesses, and confront any person the agency presents"); Formation of Government Contracts, supra note 12, at 494-96.

133 See supra note 39 and accompanying text.

${ }_{134}$ See, e.g., Caroline Daniel and Demetri Sevastopulo, Inside the 'iron triangle': armed with e-mails, John McCain battles the US defence establishment, Fin. Times, Jan. 28, 2005.
} 


\section{Conclusion}

As the discussion above reflects, although the laws and practices that shape the U.S. federal procurement system have a deep and rich history of their own, in many ways they reflect parallel developments emerging in other jurisdictions. The history of the U.S. procurement system shows that a regulatory structure can continue to evolve over many centuries, accumulating lessons learned in a system that honors the rule of law, and sharing those lessons with other systems around the world. 